\title{
Changing Trainee Teachers' Perceptions of School-Based Assessment in Malaysia: an Exploratory Study
}

\author{
Mark Smith \\ University of Brunei Darussalam \\ Jalan Tungku Link, Gadong BE 1410, Brunei Darussalam \\ Orchid: 0000-0002-7807-1779
Juwairiyyah Ahmadun
IPG Gaya Campus \\ Kota Kinabalu
}

\begin{abstract}
School-based assessment, while quite established in many Western countries, is still relatively new in the Asian education context. Consequently, operational problems such as time constraints, lack of teacher skills and inadequate computer management systems have hampered implementation efforts. While studies have been conducted which examined these issues, few if any have examined how trainee teachers feel. The following paper addresses this issue through an exploratory study on 25 first year bachelor of education students from a Malaysian Institute of Teacher Education. Findings showed that the majority of students were more positive towards a student-centred and formative learning approach after the students had experienced a teaching unit based on formative assessment principles. The findings also indicated that cultural influence may play a considerable part in the success or otherwise of school-based assessment endeavours. Results of this study may serve as a useful starting point for researchers interested in more classroom-based explorations of school-based assessment in Asia.
\end{abstract}

Keywords: school-based assessment, classroom-based explorations, Malaysia, teacher education

School-based assessment (SBA), with emphasis on task-based student-focussed learning, formative assessment and critical thinking skills has been an established practice in many Western countries from as early as the 1970's (e.g., Allen, 2012; Brown \& Harris, 2009; Brown \& Hattie, 2009; Cumming \& Maxwell, 2004; Hutchinson \& Hayward, 2005). In contrast, SBA is a relatively recent addition to Asian pedagogy (Chong, 2009; Davison, 2007). SBA in Malaysia, for instance, commenced in 2011 as part of the Ministry of Education's plan to transform the national education system by encouraging teachers to increase their repertoire of

Language Education in Asia, 2017, 8(1), 26-47. http://dx.doi.org/10.5746/LEiA/17/V8/11/A03/Smith_Ahmadun 
assessment tasks which are authentic, contextualized and able to enhance higher-order thinking skills necessary for the $21^{\text {st }}$ century. Like Western education systems, the move to SBA reflected a paradigm shift from Assessment of Learning (AoL) to Assessment for Learning (AfL) (Brookhart, 2007; Darling-Hammond \& McCloskey, 2008). Traditionally, AoL is used in tests and exams to report the final or overall achievement of students (Vlachou, 2015) while the purpose of AfL is to enhance both teaching and learning (Black, Harrison \& Lee, 2003; Earl, 2012; Heritage, 2013; Wiliam, 2011).

Despite the many benefits of SBA (e.g.,Clarke, Timperley \& Hattie, 2001; Klute, Apthorp, Harlacher \& Reale, 2017; Marsh, 2007; McManus, 2008) success to date in Malaysia has been hampered by a number of issues, including insufficient guidelines, lack of teachers' knowledge and time constraints (e.g., Abas, Rasali \& Rahmat, 2013, Fook \& Sidhu, 2006; Majid, 2011; Malakolunthu \& Hoon, 2010; Mansor, Leng, Rasul, Raof \& Yusoff, 2013 ; Omar \& Sinnasamy, 2017; Rashid \& Jaidin, 2014; Sardareh, 2016; Veloo, Krishnasamy \& Md-Ali, 2015). As a consequence, Abdullah, Idris, Hamzah \& Sembak (2015) believe that only moderate levels of SBA implementation are presently occurring.

While studies which document implementation problems dominate the literature, few studies have explored the cultural effect on school-based assessment and even fewer on how prospective teachers feel about school-based assessment. Students' perceptions of educational innovations are important as they may motivate students to engage with the reform, and, therefore, impact upon the benefits that they might derive from it (Tong, 2016). While Kamarulzaman (2014) examined critical thinking skills of pre-service teachers, it was small in nature and did not address the issue of culture. This study attempts to address this imbalance by exploring the perceptions of 25 first-year trainee teachers to school-based assessment. Using the website http://www.assessmentforlearning.edu.au/default.asp as a model for intervention, this study hopes to expose the students to the value of quality formative assessment in the belief that students would use formative assessment more readily in their future teaching careers. The study begins with an outline of the relevant literature followed by a description of methodology and procedures, followed by an analysis of results and discussion.

\section{Literature Review}

There is considerable research concerning school-based assessment in developed Western countries such as Australia, USA, New Zealand, United Kingdom and Canada (e.g., Hattie \& Brown, 2007; Kingston \& Nash, 2011; Klute, et al, 2017; Tomlinson, 1996). More recently school-based assessment has begun to make inroads into Asia (e.g., Butler, 2011; Chong, 2009; Davison, 2007). However, studies to date in Malaysia have primarily focused on implementation issues of SBA. Consequently, the following review will concentrate more on the nature of school-based assessment, particularly in relation to Asia. It will also focus on the less explored area of culture and SBA implementation.

\section{Types of Assessment}

Assessment serves a variety of purposes including to: track progress, make comparisons, monitor achievement, identify misconceptions and identify strengths and weaknesses (Glazer, 2014). Ultimately, in the form of a grade, it can have a profound influence on peoples' lives by 
determining academic and career opportunities of students. In Hong Kong, for instance, high stakes external exams are the key to social mobility through access to greater employment opportunities (Berry, 2011). Consequently, Glazer (2014) recommends that educators ensure that assessment practice is meaningful but also fair and consistent. There are generally two forms of assessment available to educators: summative and formative. The latter form is more traditional in nature, largely concerned with the final or summative grade at the end of a unit, semester, grade or programme, and is usually represented by a numerical or letter grade score (Glazer, 2014; Isaacs, Zara, Herbert, Coombs \& Smith, 2013). On the other hand, formative assessment is less formal, takes in a variety of forms rather than just test or examination and most importantly provides feedback to both students and teachers during the learning process (Glazer, 2014). This contrasts greatly with summative assessment, which stops at the judgement level, leaving the students with a grade but little idea of what they did well or how they could improve. A further important difference in formative assessment is the greater engagement levels as teachers and students gather, interpret, and use evidence about what and how students learn in order to facilitate further student learning (Klute et al, 2017).

\section{Nature of SBA}

School-based assessment is a form of assessment which is embedded in the teaching and learning process. According to the Hong Kong Examinations and Assessment Authority (HKEAA; n.d.), SBA is aligned within the educational philosophy of "assessment for learning" and has the following characteristics.

- Involves sharing learning goals with students

- Aims to help pupils to know and recognise the standards they are aiming for

- Involves students in self-assessment

- Involves both teachers and students reviewing and reflecting on assessment data

- Provides feedback which leads to students recognizing the next steps in their learning

- It complements other forms of assessment, including external examinations

School-based assessment arose due to the shift in paradigm from Assessment of Learning (AoL) to Assessment for Learning (AfL) (Reyneke, 2016). While SBA has existed in Western educational systems such as Australia, New Zealand and Canada much longer than in Asia, external testing still dominates the curricula in most world countries (Darling-Hammond \& McCloskey, 2008; Long, 2006; Mak \& Lee, 2014; McCollow, 2006). Reyneke (2016) suggests that the reason for this dominance lay in the traditional practice of setting standards to evaluate performance and ensuring reliability and validity. The assumption here, of course, is that SBA may not have sufficient reliability and validity. This is contradicted, however, by the HKEAA, (n.d. ), who claim that both reliability and validity levels are in fact increased through greater opportunities for reflection and standardization.

Given the traditional bifurcation between the two forms of assessment, Carless (2007) prefers to use the term Learning-Oriented Assessment (LOA). With this term, learning comes first, both in formal and informal assessments. Consequently, all assessments, whether they are high-stakes exams or school-based assessment, should contribute to effective learning and reliable outcomes. Despite what terminology is used for SBA, all labels represent a shift away from traditional norm-referenced assessments to greater assessment emphasis at the school and 
classroom level. This view is supported by Allen (2012) who suggests that a quality assessment programme combines both formative (for learning) and summative (of learning) approaches.

\section{SBA in Malaysia}

As mentioned, there is no shortage of research pertaining to the problems faced by teachers in implementing SBA in Malaysia. A qualitative study by Malakolunthu \& Hoon (2010) on form 2 secondary teachers unearthed a lack of teachers' knowledge, lack of monitoring, and insufficient guidelines. A survey study by Majid (2011), examined the concerns of 40 English teachers and found that teachers had high levels of concern in all the five Stages of Concern Model. Of particular concern for the participants were: how to modify SBA on students' learning experiences and how to use feedback from students to change SBA. The issue of time constraints is supported in a survey study by (Abas, Rasali \& Rahmat 2013) which found that most respondents believed that SBA was consuming too much time. Similar results were found in Omar \& Sinnasamy's (2017) study of oral school-based assessment in rural schools in Sabah. Technology concerns were identified by Abas et al, (2013) whose study revealed a lack of training awareness by teachers in using the SPBBS online system to record SBA results. Similarly, Fook \& Sidhu (2006) revealed that the respondents in their survey study did not have sufficient knowledge to implement SBA effectively. In a more recent study, Veloo, Krishnasamy \& Md-Ali (2015) found that, although the 155 teachers in their survey study claimed to be knowledgeable about SBA, they lacked sufficient knowledge to implement it. Concerns in carrying out SBA are also evident in other Asian countries. In Hong Kong for instance, Berry (2010) argued that, while Hong Kong has accepted AfL for some time, the country has yet to implement it effectively. Similarly, a case study in China by Berry \& Gao (2009) revealed that teachers lacked understanding of assessment and consequently were unable to fulfil the assessment reform standards. Finally, a Bruneian study by Rashid \& Jaidin (2014) involving 15 primary teachers indicated that the participants' use of feedback in SBA was very limited. While the above problems are indeed serious, underlining them, however, are far deeper problems embedded in the social structure of Malaysian and the wider Asian society.

\section{Culture and School-Based Assessment}

In implementing any educational reform, culture, at the societal, school, and classroom level, plays a significant role in a programme's success. Despite this, studies focusing on the role of culture and school-based assessment are rare. Sharkey \& Murnane (2006) believe that successful implementation of formative assessment systems (such as SBA) require a school culture that embraces the idea that achievement of students is the responsibility of all teaching staff and the success of such programmes are dependent on continued learning. However, if the wider society values high stakes external exam results over formative means, such as SBA, the transition to continuous assessment becomes that more challenging (Rashid \& Jaidin, 2014). The mixed success of SBA in Asian countries, including Malaysia, Bangladesh, Thailand, Indonesia and Singapore is a result of prevailing beliefs and practices that favour high pressure tests for summative purposes (Berry, 2011). In Hong Kong, for example, Kennedy (2013) notes that structured exams in Hong Kong are seen as part of the social structure of society. This is reflected in practices such as private tutoring, mock exams, drilling of students and teaching to the exam. Of course, emphasis on high stakes exams is not limited to Hong Kong. In Malaysia, levels of private tutoring have been growing for decades. Arshad 
(2004) refers to it as the tuition syndrome and believes that the strong emphasis on examinations in Malaysia gave rise to, and sustain this industry. Similar practices are also evident in other Asian countries such as Brunei (Rashid \& Jaidin, 2014) and China (Jing, Hang \& Zhang, 2007). It is as if parents from these countries expect and trust external examinations because of the social mobility that success in standardized tests can provide for their children, rather than the alternative of school-based assessment, which introduces elements of uncertainty in relation to aspects such as fairness and transparency (Kennedy, 2013). Naturally, these traditional views on assessment affect trainee teachers as well. The trainee teachers, in the present study, for instance, are products of older ways of thinking. They finished their schooling before the implementation of SBA in 2011 and hence are unfamiliar with more student-centred approaches to education such as task-based learning and peer and self-assessments. Consequently, for these trainees, their past assessment experiences throughout their schooling may strongly influence their present and future practices in assessment (Xu \& Liu, 2009).

Given this context and, on the basis of research that suggests teachers are not prepared for SBA, it was expected that the students would have negative perceptions of SBA. Our research task, therefore, was: How could we change the perceptions of our students to formative schoolbased assessment, given the strong cultural propensity towards summative assessment? Chong (2009) believes that the challenge is to change the mind-set of the stakeholders by helping students to understand SBA. Chong's emphasis on exposure is supported in the findings of Omar \& Sinnasamy (2017), which inferred that teachers' inability to implement SBA may have been caused by a lack of exposure to formative techniques and strategies. One such strategy which exposes students to formative assessment through greater involvement and transparency is assessment for learning (AfL). The Assessment Reform Group (1999, p.7) AfL encourages teachers to employ the following characteristics in their assessment:

- Learning goals should be shared with students

- Students need help to understand the standards they are aiming for

- Students should be involved in self (and peer assessment)

- Students require feedback to help them recognise their next steps

\section{Methods}

The AfL model was used in this study as it encompasses vital aspects such as shared assessment and feedback, recommended by by (the HKEAA, n.d.) as essential components of SBA. Given our students' apparent cultural propensity towards teacher-centred approaches, our research considered the following questions:

1. How do our students perceive school-based assessment and why?

2. Will students' perceptions of school-based assessment change after being exposed to more formative assessment techniques such as AfL?

\section{Participants}

Twenty-five students (21 female, 4 male) undertaking the first-year Bachelor of Teacher Education programme at a teacher education institute in East Malaysia took part in the study. The students were aged between 18 and 22. A convenience sample was chosen because the participants finished their secondary schooling prior to 2011. Consequently, they were 
relatively unfamiliar with the new curriculum, which focuses on formative assessment and higher-order thinking skills.

\section{Instruments and Procedure}

A three-step descriptive analysis methodology was utilised to conduct the study. Descriptive analysis provides a knowledge base which can provide the basis for further study (Travers, 1978). The first step involved a discussion and brief survey of students to ascertain their preconceived views of SBA. Students were given fifteen minutes to record their thoughts on the use of SBA in schools. (See Appendix A). The second, or experimental stage, involved exposing the participants to a more formative assessment environment, reflective of school-based assessment. To achieve this, students were introduced to a formative assessment task based on resources provided by the Australian website www.assessmentforlearning.edu.au. The website provides web-based professional learning resources that enable teachers to plan task-based lessons that incorporate self, peer, and teacher feedback through the use of rubrics. The instrument was chosen as its structure closely aligns with the principles of effective assessment for learning as recommended by The Assessment Reform group (1999) as well as the (HKEAA, n.d.). Finally, to gauge the perceptions of the participants towards the task-based formative approach versus a traditional approach, two structured surveys were distributed to the students (see Appendices B \& C). Whilst surveys are often criticised for reflecting reported views only, they can provide valuable feedback to teachers to improve learning and teaching $(\mathrm{H} s i e h$ \& Chu, 2006). Before distribution, the questionnaires were checked by two teacher colleagues for validity.

\section{Analysis}

Both initial survey and questionnaire results were analysed through descriptive analysis. Participants were coded according to sex ( $\mathrm{M}$ or F) and given a number according to how the students appeared on the class register. Responses were recorded and tallied in an endeavour to reveal significant trends.

\section{The Task}

Based on the principles of assessment for learning, the researchers chose a lesson on measurement called Capacity Sculpture from the Queensland task matrix in www.assessmentforlearning.com.au In the lesson, students (in groups of four) were required to build a sculpture from a number of junk objects. Success criteria involved ability to measure accurately and to use problem-solving strategies. To highlight the differences between a formative and summative approach, researchers conducted the lesson using both studentcentred and teacher-centred approaches. In the first session, a teacher-centred approach was used, covering exactly the same content but not giving students any opportunities for peer or self-assessment. No rubrics were used and all feedback came from the teachers. When the lesson was taught a second time, students received not only a task-based rubric but also feedback from their fellow group members and from other groups (peer evaluation).

In order to share learning goals with the students, explicit task instructions were given out as well as student rubrics based on 3 levels of performance: high, medium and low (see 
Appendices D \& E). Access to these documents enabled our students to firstly understand what was required and secondly, to take a more active role in the learning process (Marsh, 2007). Using the rubrics not only for their own groups but also to assess their peers, enabled students to be more involved in the assessment process and receive valuable feedback from a number of their classmates. Individual feedback came in the form of a completed teacher rubric for each student. Finally, as the researchers wanted to portray formative assessment as an ongoing cyclical process, (Heredia, Furtak, Morrison \& Renga, 2016), diagnostic grids were given to the students to indicate how a teacher utilises the rubric results to determine future needs (see Appendix F).

\section{Main Findings}

Initial feedback from the participants before intervention (see Appendix A) provided mostly negative feedback towards school-based assessment, with some considering SBA a burden to teachers. Student F2 wrote:

It takes a lot of time to prepare the activities, and at the same time, it would be unfair to the student.

Similarly, M5 wrote:

Teachers do not have time to prepare so many activities as they have lots of administrative tasks to complete.

It is interesting that such views are similar to results of teacher studies conducted by Majid (2011), Abas, et al, (2013) and Omar \& Sinnasamy (2017). However, after intervention utilising a formative, student-centred approach, participants' attitudes changed markedly. These are reflected by the results from both surveys shown below.

\section{Feelings towards the Activity-Based Approach}

The first question asked the participants to explain their feelings while undertaking the formative, task-based activities found in the unit Capacity Sculpture. The vast majority of the students $(88 \%)$ reported feelings of happiness while carrying out the activities. To support their responses, $28 \%$ of participants claimed that it was because of the co-operation or interaction involved in the group activities. Other main supporting reasons included the involvement or physical movement of the activities (16\%) and that the activities were new or different $(16 \%)$.

\section{Future Intentions}

When asked if they would conduct formative, task-based activities with their own students in their future schools, a resounding $92 \%$ of respondents affirmed in the positive. Justifying the use of formative task-based activities in school, more than half of the respondents (52\%) indicated that it was because of the fun element associated with task-based activities. Other strong motives included attracting student interest (12\%) and co-operative skills ( $8 \%)$. 


\section{Preferred Strategy}

Item one in questionnaire B asked the participants to decide which strategy (teacher-centred or student-centred) they preferred. Seventeen students (68\%) indicated a preference for the student-centred approach. The main reasons for choosing the student-centred approach included greater involvement in the activity (35\%), (to) give experience (34\%) and better understanding (24\%). Significantly, however, almost a third of the students stated that they preferred the teacher-centred approach. Main justifications were: increased understanding $(12 \%)$, need for guidance $(12 \%)$ and learning alone (6\%). The responses from these eight students may well infer a belief that a teacher-centred approach leads to greater understanding and provides more guidance, something that they may perceive as somewhat lacking under a student-centred approach.

\section{Perceived Strengths and Weaknesses of Each Approach}

Items 3 and 4 required participants to name the perceived strengths and weaknesses of the teacher centred and student centred approaches (Table 1).

\section{Table 1}

\section{Perceived Strengths and Weaknesses of Each Approach}

\begin{tabular}{|c|c|c|c|}
\hline \multicolumn{2}{|l|}{ Strengths } & \multicolumn{2}{|l|}{ Student-centred approach } \\
\hline \multicolumn{2}{|l|}{ Teacher-centred approach } & & \\
\hline Greater classroom control & $27.9 \%$ & Greater student understanding & $36.8 \%$ \\
\hline Teacher-guided & $10.9 \%$ & Greater student involvement & $28.9 \%$ \\
\hline \multicolumn{2}{|l|}{ Weaknesses } & \multirow{5}{*}{$\begin{array}{l}\text { Student-centred approach } \\
\text { Lack of focus/attention }\end{array}$} & \multirow{5}{*}{$25 \%$} \\
\hline Teacher-centred approac & & & \\
\hline Boring & $38.2 \%$ & & \\
\hline Lack of student focus & $17.6 \%$ & & \\
\hline Lack of teacher focus & $17.6 \%$ & & \\
\hline
\end{tabular}

In relation to strengths, it is evident that greater classroom control $(27.9 \%)$ was considered to be the main strength of a teacher-centred approach, whilst greater understanding $(36.8 \%)$ and greater student involvement $(28.9 \%)$ were deemed to be the main strengths of the studentcentred approach. Interestingly, fun learning was only reported as a strength by $10.5 \%$ of the respondents. The low response perhaps implies that students realize that there is more to student-centred approaches than simply having fun.

The main weakness of the teacher-centred approach, according to the participants was that it was boring (38.2\%). Other perceived weaknesses included: lack of student and teacher focus (both $17.6 \%$ ). On the other hand, given the strong emphasis on greater classroom control in the teacher-centred approach mentioned earlier, it is not surprising that most students felt that the greatest weakness of the formative approach was a lack of focus/attention (25\%).

\section{Approach That Participants Intend to Use When Teaching}

Despite almost $70 \%$ of participants in the first questionnaire favouring a student-centred approach, less than half (44\%) indicated an intention to use the approach in their future teaching. The remaining 14 participants (56\%) indicated an intention to use both approaches, i.e. teacher centred and student centred approaches. Given that the possible responses to the 
question did not provide the participants with a both option, the result was surprising. However, despite $56 \%$ of the participants intending to use both approaches, their reasons place little credence in the teacher-centred approach. For instance, of the twelve reasons, it seems that only one, balance/various types of approaches (14\%) provides real evidence of a desire for a balanced approach. The other main reasons given: student involvement (29\%), effective learning (29\%), an active class (14\%), creativity (7\%), lively class $(7 \%)$, co-operation $(7 \%)$ and thinking skills $(7 \%)$, may all well be construed as supporting a student-centred, rather than teacher-centred approach.

\section{Discussion}

This research introduced AfL principles to a group of pre-service teachers, in the hope of instilling positive perceptions towards school-based assessment. Initially, it was found that the students in the study were products of their own traditional learning backgrounds. Consequently, like their practising peers, SBA was initially perceived to be a considerable burden on teachers. However, after participating in an intervention wherein they experienced a task-based formative approach, the students' views shifted significantly in favour of the formative assessment approach. Through active involvement in the assessment process using real tasks, students became more empowered in AfL concepts (Berry, 2011). Overall, the research intervention was successful in changing the mind-set of our stakeholders by helping them to understand the formative nature of school-based assessment (Chong, 2009).

Feedback from the participants showed that the notions of co-operation and interaction were important by-products of the formative approach. In fact, out of the ten questions in the two questionnaires, the notions of co-operation and interaction were reported as favourable in eight of the questions. This positive response is encouraging, given the crucial importance of the ability to learn, collaborate and solve problems in today's society (Griffin, McGaw \& Care, 2014). Further, a recent study by (Jacobson-Lundeberg, 2016) on the role of communication and collaboration, found that the teaching of these skills empowers students to learn other $21^{\text {st }}$ century skills of critical thinking and creativity.

Also significant was the fun element of task-based learning. The notion of fun arose to a significant degree in two of the questions. The strong emphasis on fun and co-operation may well be attributed to the cultural values of a high-context culture such as Malaysia. Slacks et al.'s "turn-taking framework" in Wolfartsberger (2011) indicates that high-context cultures such as those found in South East Asia place high emphasis on a collectivist, harmonious and nonconfrontational approach. The ASEAN organisation itself, consisting of ten countries in South East Asia, was set up to harmonize its ten member countries and bring greater benefits to all. While harmonious accord may be helpful in developing the soft skill of communication, it does very little in developing higher level thinking skills such as critical thinking which requires students to provide constructive feedback. However, in terms of strengths, it was quite significant that greater understanding was considered the major strength of a student-centred approach. In other words, fun was considered important, but not nearly as important as the need for greater understanding. While this is a pleasing result, the fact that almost a third of respondents indicated an intention to use both approaches in the future is also highly significant and worthy of further explanation. Their response may well be reflective of the very 
strong cultural impact mentioned earlier in the study. The study sample was brought up in a culture whereby teachers are in control in a predominantly teacher-centred learning environment. Students were familiar with quiet, teacher-controlled classrooms, which was strongly reflected in their responses. Perhaps their own teachers felt more comfortable with more traditional methods of teaching. This notion mirrors the work of Marsh (2007), who states that many teachers encourage more traditional methods because they are well-known and these forms of teaching do not require the use of potentially threatening open-ended, studentcentred activities. The apparent avoidance of confrontation is a cultural aspect which educational authorities will need to examine closely if more student-empowering formative methods are going to be successful. On the other hand, it was interesting in that, it was the collectivist Malay values such as co-operation, interaction, and fun that most appealed to the students in our study. In this respect, therefore, cultural traits of co-operation and teamwork can provide a positive contribution to greater acceptance of SBA and these values should be embraced by teachers. However, as co-operative skills make up only some of the $21^{\text {st }}$ century skills, efforts are still needed to ensure greater use of problem solving and critical thinking skills.

The study is not without limitations. Firstly, the students chosen were from a traditional school background and had no previous exposure to SBA, and hence would be expected to be wary of or negative towards new formative approaches. However, the fact that two-thirds of the respondents were actually positive towards SBA (after intervention) is perhaps testament to the potential of SBA. A second limitation relates to the use of a convenience sampling procedure. Whilst the convenience sample in this study facilitated accomplishment of the task, it is acknowledged that reflecting reported views only, lacks external validity. To obtain greater external validity it is recommended that similar studies be conducted in the future on a larger scale, incorporating students who have been exposed to SBA as school students.

\section{Conclusion and recommendations}

This study has extended the current literature by demonstrating that, given the right tools and support, students (and teachers) can be informed and confident in implementing formative SBA. The findings suggest that trainee teachers are similar to practising teachers, in that they lack the strategies to implement SBA effectively. The study also reinforces previous findings regarding the positive effects of formative assessment (Kingston \& Nash, 2011; Klute et al, 2017). Whilst the study was conducted in Malaysia, cultural similarities mean that it has wide application for other Asian countries grappling with SBA applications. In particular, given the common Malay culture which values co-operation, Brunei may well benefit in greater use of collaborative task-based assessment, such as those found in the assessmentforlearning website. Further, given the research evidence that suggests that many teachers are lacking assessment literacy, this approach may also be beneficial to other Asian countries such as Hong Kong and China, by showing students and teachers how to apply SBA using real task based activities. To increase levels of assessment literacy, especially in Malaysia, it is recommended that educational bodies consider the implementation of systematic in-service programmes on formative assessment, especially for those teachers who completed their schooling prior to 2011. It is proposed that these programmes be aligned to Afl principles and thus cover areas such as feedback, assessment criterion, peer and self- assessment and transparency. It is 
acknowledged that these initiatives will take time, especially given the strong cultural preference for summative assessment which currently exists in the community. A community approach, therefore, in which whole schools and their communities explore AfL, is posited as the best way to counteract longstanding preferences for high stakes testing, which presently provide little in the way of $21^{\text {st }}$ century skills, ironically, the same skills sought by many educational authorities in the first place.

\section{Author Note}

Mark Smith is a teacher educator with over twenty years' experience at the primary and tertiary levels. He currently works as an educational officer at the Centre For Lifelong Learning, University Brunei where he teaches communication and language proficiency.

Juwairiyyah Ahmadun has had more than twenty years of teaching experience in the secondary and tertiary levels in Malaysia. Juwairiyyah joined the teachers' training institute in 2000. She has supervised first degree students on action research in pedagogy since 2010. 


\section{References}

Abas, A., Rasali, R., \& Rahmat, A. R. (2013). A Study on ICT Related Issues for School-Based Assessment Online System in Malaysian Secondary Education. Retrieved Feb 12, 2017, from http://www.wseas.us/elibrary/conferences/2014/CambridgeUSA/COMP/COMP-28.pdf

Abdullah, N., Idris, N., Hamzah, M. S. G., \& Sembak, S. (2015). Planning and Implementation of School-Based Assessment (SBA) Among Teachers. Procedia-Social and Behavioral Sciences, 211, 247-254. https://doi.org/10.1016/j.sbspro.2015.11.031

Allen, R. (2012). "Developing the enabling context for school-based assessment in Queensland, Australia." Systems Approach for Better Education Results (SABER) (2012). Retrieved Jan 9, 2017, from http://www.wds.worldbank.org/external/default/WDSContentServer/WDSP/IB/2013/01 /18/000425962_20130118160041/Rendered/PDF/NonAsciiFileName0.pdf

Arshad, M. (2004). Amalan tuisyen dalam sistem pendidikan. Portal Pendidikan Utusan. Retrieved online from: http://www.geocities.com/pendidikmy/berita/berita012004.html.

Assessment For Learning. (n.d.) Retrieved April 15, 2016, from http://www.assessmentforlearning.edu.au/assessment_tasks/capacitysculpture/capacity _sculpture_-_1_description.html

Assessment Reform Group. (1999). Assessment for learning: Beyond the black box. Université de Cambridge, School of Education. Retrieved Dec14, 2017, from http://www.opengrey.eu/item/display/10068/566551

Berry, R. (2010). Teachers' Orientations towards Selecting Assessment Strategies. New Horizons in Education, 58(1), 96-107.

Berry, R. (2011). Assessment reforms around the world. In Assessment reform in education (pp. 89-102). Springer Netherlands. https://doi.org/10.1007/978-94-007-0729-0_7

Berry, R., \& Gao, L. (2009). Teachers'classroom assessment practice in China. Paper presented at the International Conference on Primary Education. Hong Kong Institute of Education, Hong Kong.

Black, P., Harrison, C., \& Lee, C. (2003). Assessment for learning: Putting it into practice. McGraw-Hill Education (UK).

Brookhart, S. M. (2007). Expanding views about formative classroom assessment: A review of the literature. Formative classroom assessment: Theory into practice, 43-62.

Brown, G., \& Harris, L. (2009). Unintended consequences of using tests to improve learning: How improvement-oriented resources heighten conceptions of assessment as school accountability. Journal of MultiDisciplinary Evaluation, 6(12), 68-91. Retrieved Feb 11, 2017, from http://www.jmde.com

Brown, G. T. L., \& Hattie, J. A. (2009). Understanding teachers' thinking about assessment: Insights for developing better educational assessments. In annual conference of the National Council for Measurement in Education, San Diego, CA. Retrieved June 10, 2017, from http://repository.lib.ied.edu.hk/pubdata/ir/link/pub/2009\%20Brown\%20and\%20Hattie $\% 20$ NCME\%20v4.pdf 
Butler, Y. G. (2011). The implementation of communicative and task-based language teaching in the Asia-Pacific region. Annual Review of Applied Linguistics, 31, 36-57. https://doi.org/10.1017/S0267190511000122

Carless, D. (2007). Learning- oriented assessment: conceptual bases and practical implications. Innovations in Education and Teaching International, 44(1), 57-66. https://doi.org/10.1080/14703290601081332

Chong, K. K. (2009, September). Whither school-based coursework assessment in Singapore. In International Association of Educational Assessment annual conference, September (pp. 13-18). Retrieved November 14, 2016, from http://www.iaea.info/documents/paper_4d73afd.pdf

Clarke, S., Timperley, H., \& Hattie, J. (2001). Unlocking formative assessment . London: Hodder and Stoughton.

Cumming, J.J., \& Maxwell, G.S. (2004). Assessment in Australian schools: Current practice and trends. Assessment in Education, 11(1), 9108. Retrieved February 10, 2017, from https://doi.org/10.1080/0969594042000209010

Darling-Hammond, L., \& McCloskey, L. (2008). Assessment for Learning around the World What Would it Mean to Be Internationally Competitive?. Phi Delta Kappan, 90(4), 263-272. https://doi.org/10.1177/003172170809000407

Davison, C. (2007). Views from the chalkface: English language school-based assessment in Hong Kong. Language Assessment Quarterly, 4(1), 37-68. https://doi.org/10.1080/15434300701348359

Earl, L. M. (2012). Assessment as learning: Using classroom assessment to maximize student learning. Corwin Press.

Fook, C. Y., \& Sidhu, G. K. (2006). School-based assessment among ESL teachers in Malaysia Secondary schools. Retrieved May 9, 2016, from http://medc.com.my/medc/journals/volume9/chan\%20yuen.pdf

Glazer, N. (2014). Formative plus Summative Assessment in Large Undergraduate Courses: Why Both? International Journal of Teaching and Learning in Higher Education, 26(2), 276-286. Retrieved August 17, 2017, from http://www.isetl.org/ijtlhe/

Griffin, P., McGaw, B. \& Care, E., Eds. (2014). Assessment and teaching of 21 st century skills: Methods and approach. Springer.

Hattie, J. A., \& Brown, G. T. (2007). Technology for school-based assessment and assessment for learning: Development principles from New Zealand. Journal of Educational Technology Systems, 36(2), 189-201. https://doi.org/10.2190/ET.36.2.g

Heredia, S. C., Furtak, E. M., Morrison, D., \& Renga, I. P. (2016). Science Teachers' Representations of Classroom Practice in the Process of Formative Assessment Design. Journal of Science Teacher Education, 27(7), 697-716. https://doi.org/10.1007/s10972016-9482-3

Heritage, M. (2013). Formative Assessment in Practice: A Process of Inquiry and Action. Harvard Education Press. 8 Story Street First Floor, Cambridge, MA 02138.

Hong Kong Examinations and Assessment Authority. (n.d.). Retrieved September 14, 2017 from http://www.hkeaa.edu.hk/DocLibrary/SBA/HKDSE/Eng_DVD/sba_definition.html

Hsieh, S. M., \& Chu, S. C. (2006). Making "friends" an English learning partner. New aspects of English language teaching and learning, 351-361. Retrieved March 19, 2017, from http://120.106.195.12/handle/310904600Q/2228 
Hutchinson, C., \& Hayward, L. (2005). The journey so far: Assessment for learning in Scotland. Curriculum Journal, 16(2), 225-248. https://doi.org/10.1080/09585170500136184

Isaacs, T., Zara, C., Herbert, G., Coombs, S. J., \& Smith, C. (2013). Key concepts in educational assessment. Sage. https://doi.org/10.4135/9781473915077

Jacobson-Lundeberg, V. (2016). Pedagogical Implementation of 21st Century Skills. Educational Leadership and Administration, 27, 82.

Jing, L., Hang, S., \& Zhang, C. (2007). Investigation and analysis of implementation of assessment in primary English teaching. Teaching and Management, 18(6), 18-22.

Kamarulzaman, W. (2014). The Exploration of School-Based Assessment (SBA) on Critical Thinking Skills in Science Subject of Malaysian Primary School Students. Retrieved July 28, 2017, from https://papers.ssrn.com/sol3/papers.cfm?abstract_id=2394392 https://doi.org/10.2139/ssrn.2394392

Kennedy, K. J. (2013). High stakes school based assessment and cultural values: Beyond issues of validity. Meeting paper presented the Cambridge Horizons Seminar, June 2013, Subang Jaya. Retrieved April 12, 2017, from http://www.iaea2008.cambridgeassessment.org.uk/ca/digitalAssets/207402_Kerry_Ken nedy_presentation_slides.pdf

Kingston, N., \& Nash, B. (2011). Formative assessment: A meta- analysis and a call for research. Educational measurement: Issues and practice, 30(4), 28-37. https://doi.org/10.1111/j.1745-3992.2011.00220.x

Klute, M., Apthorp, H., Harlacher, J., \& Reale, M. (2017). Formative assessment and elementary school student academic achievement: A review of the evidence. Retrieved July 13, 2017, from http://files.eric.ed.gov/fulltext/ED572929.pdf

Long, C. (2006, May). Realising the potential of school based assessment. In International Association for Educational Assessment Conference.

McCollow, J., \& noted by Reid, A. (2006). Defending school-based assessment. Professional Magazine, 21, 10-13.

McManus, S. (2008). Attributes of effective formative assessment. Washington, DC: Council for Chief State School Officers. Retrieved June 15, 2016, from http://www.ccsso.org/publications/details.cfm?PublicationsID=362

Majid, F. A. (2011). School-Based Assessment in Malaysian Schools: The Concerns of the English Teachers. Online Submission. Retrieved June 12, 2017, from http://eric.ed.gov/?id=ED524802

Mak, P., \& Lee, I. (2014). Implementing assessment for learning in L2 writing: An activity theory perspective. System, 47, 73-87. https://doi.org/10.1016/j.system.2014.09.018

Malakolunthu, S., \& Hoon, S. K. (2010). Teacher perspectives of school-based assessment in a secondary school in Kuala Lumpur. Procedia-Social and Behavioral Sciences, 9, 11701176. https://doi.org/10.1016/j.sbspro.2010.12.302

Mansor, A. N., Leng, O. H., Rasul, M. S., Raof, R. A., \& Yusoff, N. (2013). The benefits of school-based assessment. Asian Social Science, 9(8), 101. https://doi.org/10.5539/ass.v9n8p101

Marsh, C. J. (2007). A critical analysis of the use of formative assessment in schools. Educational Research for Policy and Practice 6, 25-29. https://doi.org/10.1007/s10671-007-9024-z 
Omar, H. M., \& Sinnasamy, P. (2017). BETWEEN THE IDEAL AND REALITY: TEACHERS'PERCEPTION OF THE IMPLEMENTATION OF SCHOOL-BASED ORAL ENGLISH ASSESSMENT. The English Teacher, 17.Saklofske, D. H., \& Janzen, H. L. (1990). School-based assessment research in Canada. McGill Journal of Education/Revue des sciences de l'éducation de McGill, 25(001). Retrieved August 19, 2017, from http://mje.mcgill.ca/index.php/MJE/article/viewArticle/7896

Rashid, R. A., \& Jaidin, J. H. (2014). Exploring Primary School Teachers' Conceptions of" Assessment for Learning". International Education Studies, 7(9), 69. https://doi.org/10.5539/ies.v7n9p69

Reyneke, M. (2016). School-based assessment in English language teaching: weighing the cow will not fatten it. Per Linguam: a Journal of Language Learning= Per Linguam: Tydskrif vir Taalaanleer, 32(2), 1-14. https://doi.org/10.5785/32-2-624

Sardareh, S. A. (2016). Formative Feedback in a Malaysian Primary School ESL Context. Malaysian Online Journal of Educational Sciences, 4(1), 1-8. Retrieved August 17, 2017, from http://files.eric.ed.gov/fulltext/EJ1088642.pdf

Sharkey, N. S., \& Murnane, R. J. (2006). Tough choices in designing a formative assessment system. American Journal of Education, 112(4), 572-588. https://doi.org/10.1086/505060

Tomlinson, P. (1996). Understanding mentoring: Reflective strategies for school-based teacher preparation. Retrieved July 18, 2017, from http://philpapers.org/rec/TOMUMR

Tong, S. Y. A. (2016). Exploring students' perception of and reaction to feedback in schoolbased assessment. Malaysian Journal of ELT Research, 7(2), 104-147. Retrieved October 29, 2017, from http://journals.melta.org.my/index.php/majer/article/viewFile/159/74

Travers, R. M. W. (1978). An introduction to educational research.

Veloo, A., Krishnasamy, H. N., \& Md-Ali, R. (2015). Teachers' Knowledge and Readiness towards Implementation of School Based Assessment in Secondary Schools. International Education Studies, 8(11), 193. https://doi.org/10.5539/ies.v8n11p193

Vlachou, M. A. (2015). Does assessment for learning work to promote student learning? The England paradigm. The Clearing House: A Journal of Educational Strategies, Issues and Ideas, 88(3), 101-107. https://doi.org/10.1080/00098655.2015.1032194

Wiliam, D. (2011). Embedded formative assessment. Solution Tree Press.

Wolfartsberger, A. (2011, May). Studying turn-taking in ELF: Raising the issues. Paper presented at the International Conference of English as a Lingua Franca, Hong Kong, China. Retrieved July 22, 2016, from http://homepage.univie.ac/anita.wolfsberger_PaperELF42011

Xu, Y., \& Liu, Y. (2009). Teacher assessment knowledge and practice: A narrative inquiry of a Chinese college EFL teacher's experience. TESOL Quarterly, 43(3), 493-513. https://doi.org/10.1002/j.1545-7249.2009.tb00246.x 


\section{Appendix A}

B.A. Teacher Education: Class (October 3, 2012) Students' feelings towards school-based assessment

What do you think about the new school-based assessment (SBA) in schools? Why? 


\section{Appendix B}

Perceptions of students after implementation of the formative group activities

1. How do you feel while doing the activities? Elaborate.

(Apakah perasaan anda semasa menjalankan aktiviti pada hari ini? Jelaskan.)

2. What do you learn from the activities?

(Apakah yang anda pelajari daripada aktiviti yang dijalankan?)

3. Would you do the activities with your students in school? Why?

(Adakah anda akan jalankan aktiviti tersebut dengan murid-murid anda di sekolah? Mengapa?)

4. What are the strengths in the activities?

(Apakah kekuatan dalam aktikiti yang dijalankan?)

5. If you are given the chance to do the activities, what are the improvement(s) that you would do?

(Jika anda diberi peluang untuk menghasilkan aktiviti pada hari ini, apakah penambahbaikan yang akan anda lakukan?) 


\section{Appendix C}

\section{Students' overall perceptions of teacher-centred versus student-centred approaches}

1. Which strategy do you prefer, the teacher-centred approach or the student-centred approach? Why?

( Strategi manakah yang anda gemari, pendekatan berpusatkan guru atau pendekatan berpusatkan murid? Mengapa?)

2. When do you think it is more suitable to use:

(Pada pendapat anda, bilakah paling sesuai untuk menggunakan:)

a. Teacher-centred approach

(pendekatan berpusatkan guru)

b. Student-centred approach

(pendekatan berpusatkan murid)

3. What are the strengths for:

(Apakah kekuatan:)

a. Teacher-centred approach

(pendekatan berpusatkan guru)

b. Student-centred approach

(pendekatan berpusatkan murid)

4. What are the weaknesses for:

(Apakah kelemahan:)

a. Teacher-centred approach

(pendekatan berpusatkan guru)

b. Student-centred approach

(pendekatan berpusatkan murid)

c. Which approach do you intend to use when you are teaching? Why?

Pendekatan manakah yang anda akan gunakan dalam pengajaran dan pembelajaran? Mengapa? 


\section{Appendix D}

\section{Task instructions: Capacity sculpture}

Your task is to make a structure or 'sculpture' out of empty containers, so that when you add up the combined capacity of all the containers it is 4.35 litres in total. The structure should be designed so that all the pieces are fixed together, and it can either stand or hang in the classroom.

\section{Things You Need to Know:}

1. Every container must be a different capacity.

2. The completed sculpture must contain at least four containers. There is no upper limit. Containers can be bottles, boxes, tubes - anything that has capacity.

3. The structure must hold together so that bits do not fall off in the classroom.

4. You must fill in the recording sheet that comes with these instructions.

5. Assessment - your sculpture will be assessed by your teacher for:

- accuracy - how close to the target it comes

- how carefully you have measured the containers

- how well you have solved the problems that will arise

- how accurately you have recorded and checked the sizes.

However, the sculpture is also a work of mathematical art, so think about the final appearance!

Source: www.assessmentforlearning.com.au 


\section{Appendix E}

\section{Student rubric for capacity sculpture task}

Name:

Date:

\begin{tabular}{|c|c|c|c|}
\hline \multirow{2}{*}{ Success criteria } & \multicolumn{3}{|c|}{ Indicators of student performance } \\
\hline & High & Medium & Low \\
\hline \multirow[t]{3}{*}{$\begin{array}{l}\text { Ability to measure } \\
\text { accurately in } \\
\text { millilitres and } \\
\text { litres using a range } \\
\text { of appropriate } \\
\text { measuring } \\
\text { instruments }\end{array}$} & $\begin{array}{l}\text { I showed I was able to } \\
\text { measure capacity very } \\
\text { accurately. } \\
\square\end{array}$ & $\begin{array}{l}\text { I showed I was able to } \\
\text { measure capacity } \\
\text { accurately most of the } \\
\text { time. } \\
\square\end{array}$ & $\begin{array}{l}\text { I showed that I } \\
\text { was able } \\
\text { occasionally to } \\
\text { measure capacity } \\
\text { accurately, } \\
\text { especially with } \\
\text { some help. } \\
\square\end{array}$ \\
\hline & $\begin{array}{l}\text { I used suitable } \\
\text { measuring instruments. } \\
\square\end{array}$ & $\begin{array}{l}\text { Most of the measuring } \\
\text { instruments I used were } \\
\text { suitable. } \\
\square\end{array}$ & \\
\hline & $\begin{array}{l}\text { I showed I was able to } \\
\text { read any scales } \\
\text { showing millilitres or } \\
\text { litres or both. } \\
\square\end{array}$ & $\begin{array}{l}\text { I was able to read scales } \\
\text { with large intervals } \\
\text { accurately. } \\
\square\end{array}$ & \\
\hline \multirow[t]{2}{*}{$\begin{array}{l}\text { Understanding of } \\
\text { the relationship } \\
\text { between millilitres } \\
\text { and litres, and } \\
\text { between millilitres } \\
\text { and fractions of a } \\
\text { litre }\end{array}$} & $\begin{array}{l}\text { I showed I was able to } \\
\text { accurately interchange } \\
\text { metric capacity units, } \\
\text { millilitres and litres. } \\
\square\end{array}$ & $\begin{array}{l}\text { I showed I was able to } \\
\text { measure litres accurately } \\
\text { and some of the time I } \\
\text { could interchange litres } \\
\text { with millilitres without } \\
\text { making errors. } \\
\square\end{array}$ & $\begin{array}{l}\text { I showed I was } \\
\text { able to measure } \\
\text { litres. } \\
\square\end{array}$ \\
\hline & $\begin{array}{l}\text { I showed I was able to } \\
\text { accurately interchange } \\
\text { fractions of a litre with } \\
\text { millilitres. } \\
\square\end{array}$ & $\begin{array}{l}\text { I could interchange } \\
\text { between millilitres and } \\
\text { fractions of litres with } \\
\text { assistance from the } \\
\text { teacher. } \\
\square\end{array}$ & \\
\hline
\end{tabular}


Research

\begin{tabular}{|c|c|c|c|}
\hline \multirow{2}{*}{ Success criteria } & \multicolumn{3}{|c|}{ Indicators of student performance } \\
\hline & High & Medium & Low \\
\hline $\begin{array}{l}\text { Ability to use } \\
\text { problem solving } \\
\text { strategies for } \\
\text { measuring and } \\
\text { solving the task } \\
\text { with accuracy }\end{array}$ & $\begin{array}{l}\text { I organised the tasks } \\
\text { logically. } \\
\square\end{array}$ & $\begin{array}{l}\text { I organised my work and I } \\
\text { worked out some mostly } \\
\text { effective ways of } \\
\text { measuring unknowns. } \\
\square\end{array}$ & $\begin{array}{l}\text { I sometimes } \\
\text { organised my } \\
\text { tasks and I } \\
\text { worked out a way } \\
\text { to measure } \\
\text { unknowns. } \\
\square\end{array}$ \\
\hline
\end{tabular}

\section{Comments:}

Source: www.assessmentforlearning.com.au 


\section{Appendix F}

\section{Diagnostic grid for capacity sculpture assessment task}

\begin{tabular}{|l|l}
\hline Class: & Date:
\end{tabular}

\begin{tabular}{|c|c|c|c|}
\hline Name of student & $\begin{array}{l}\text { Evidence of } \\
\text { accurate measuring } \\
\text { in litres and } \\
\text { millilitres using a } \\
\text { range of appropriate } \\
\text { measuring } \\
\text { instruments }\end{array}$ & $\begin{array}{l}\text { Understanding the } \\
\text { relationship } \\
\text { between millilitres } \\
\text { and litres, and } \\
\text { between millilitres } \\
\text { and fractions of a } \\
\text { litre }\end{array}$ & $\begin{array}{l}\text { Ability to use } \\
\text { problem solving } \\
\text { strategies for } \\
\text { measuring and } \\
\text { solving the task with } \\
\text { accuracy }\end{array}$ \\
\hline & & & \\
\hline & & & \\
\hline & & & \\
\hline & & & \\
\hline & & & \\
\hline & & & \\
\hline & & & \\
\hline & & & \\
\hline & & & \\
\hline & & & \\
\hline & & & \\
\hline & & & \\
\hline & & & \\
\hline & & & \\
\hline & & & \\
\hline
\end{tabular}

Source: www.assessmentforlearning.com.au 